\title{
The inward rectifier channel, ROMK, is localized to the apical tips of glial-like cells in mouse taste buds
}

\author{
Gennady Dvoryanchikov ${ }^{1,{ }^{*}, \text { Michael Sinclair }}{ }^{2,{ }^{*}}$, Isabel Perea-Martinez ${ }^{1}$, Tong Wang ${ }^{3}$, and \\ Nirupa Chaudhari ${ }^{1,2, \dagger}$ \\ ${ }^{1}$ Department of Physiology \& Biophysics, University of Miami Miller School of Medicine, Miami, \\ Florida, 33136, USA \\ 2 Program in Neurosciences, University of Miami Miller School of Medicine, Miami, Florida, \\ 33136, USA \\ ${ }^{3}$ Dept. of Cellular and Molecular Physiology, Yale School of Medicine, New Haven, CT 06520, \\ USA
}

\begin{abstract}
Cells in taste buds are closely packed with little extracellular space. Tight junctions and other barriers further limit permeability and may result in buildup of extracellular $\mathrm{K}^{+}$following action potentials. In many tissues, inwardly-rectifying $\mathrm{K}$ channels such as the Renal Outer Medullary $\mathrm{K}$ (ROMK) channel (also called Kir1.1 and derived from the Kcnj1 gene) help to redistribute $\mathrm{K}^{+}$. Using RT-PCR, we defined ROMK splice variants in mouse kidney, and report here the expression of a single one of these, ROMK2, in a subset of mouse taste cells. With qRT-PCR, we show the abundance of ROMK mRNA in taste buds is vallate $>$ foliate $\gg$ palate $\gg$ fungiform. ROMK protein follows the same pattern of prevalence as mRNA, and is essentially undetectable by immunohistochemistry in fungiform taste buds. ROMK protein is localized to the apical tips of a subset of taste cells. Using tissues from PLC $\beta 2$-GFP and GAD-GFP transgenic mice, we show that ROMK is not found in PLC $\beta 2$-expressing type II/Receptor cells or in GAD-expressing type III/Presynaptic cells. Instead, ROMK is found, by single-cell RT-PCR and immunofluorescence, in most cells that are positive for the taste glial cell marker, Ectonucleotidase2. ROMK is precisely localized to the apical tips of these cells, at and above apical tight junctions. We propose that in taste buds, ROMK in type I/glial-like cells may serve a homeostatic function, excreting excess $\mathrm{K}^{+}$ through the apical pore, and allowing excitable taste cells to maintain a hyperpolarized resting membrane potential.
\end{abstract}

\section{Keywords}

kcnj1; Kir1.1; glia; K transport; acid taste

\section{INTRODUCTION}

Taste receptor cells are electrically excitable generating action potentials to signal the presence, quality and concentration of taste stimuli (Yoshida et al, 2006). Repetitive firing results in elevation of extracellular potassium ions as the potential of cell membranes repolarize to their resting levels. Taste buds exist in a relatively enclosed environment with

\footnotetext{
${ }^{\dagger}$ Corresponding author: Nirupa Chaudhari, Ph.D., Department of Physiology and Biophysics, 1600 NW $10^{\text {th }}$ Avenue, Miami, FL 33136, Tel. (305) 243-3187, NChaudhari@ med.miami.edu.

these authors contributed equally to this work
} 
tight barriers to free diffusion of extracellular molecules (Michlig et al, 2007; Pereira et al, 2008). Electrical activity may result in the buildup of $\mathrm{K}^{+}$ions in the taste bud's small and tightly packed extracellular space. Taste buds might thus be expected to contain homeostatic mechanisms that precisely regulate the concentrations of extracellular ions, especially to clear $\mathrm{K}^{+}$rapidly. $\mathrm{K}$ channels fall into several broad classes: voltage-gated, Calciumactivated, cyclic nucleotide-gated, inward-rectifier (Kir) and leak channels that comprise a complex superfamily of sequences with upwards of 85 members in mammals (reviewed, (Yu and Catterall, 2004). Further sequence and functional diversity arises from large numbers of splice variant mRNAs and heteromeric subunit associations (reviewed, (Deutsch, 2002).

Multiple $\mathrm{K}^{+}$channels with distinct functional properties and molecular identities are reported to be expressed in taste cells (Richter et al, 2004; Lin et al, 2004b; Liu et al, 2005; Ohmoto et al, 2006). We analyzed the expression in taste buds, of the weakly inwardly rectifying and ATP-regulated K channel, ROMK (Renal Outer Medullary K channel), also known as Kir1.1, and derived from the kcnj1 gene. The Kir1.1 channel includes two membrane-spanning domains and a "P-loop" that forms a hydrophilic ion-conducting pore (Ho et al, 1993; Kubo et al, 1993; Kubo et al, 2005). Functional Kir channels, similarly to the voltage-gated $\mathrm{K}$ channels to which they are distantly related, are formed from four homologous subunits (Yang et al, 1995). The ATP-sensitivity of these channels is thought to arise from an ATP-binding regulatory domain in the C-terminus (Vanoye et al, 2002) and/or from association with other non-homologous subunits (Ruknudin et al, 1998). Inward rectifying channels are important for setting the resting membrane potential in many cells. In epithelia of the kidney tubule, Kir1.1 channels, widely termed ROMK, represent the lowconductance secretory $\mathrm{K}^{+}$channels (Wald, 1999). ROMK provides a mechanism, first, for apical $\mathrm{K}^{+}$recycling, which is essential for $\mathrm{Na}-\mathrm{K}-\mathrm{Cl}$-cotransporter (NKCC)-mediated absorption of $\mathrm{Na}^{+}, \mathrm{K}^{+}$and $\mathrm{Cl}^{-}$in the thick ascending limb and second, for $\mathrm{K}^{+}$secretion in collecting tubules. Thus, ROMK channels play an important role in maintaining overall body homeostasis of all three ions (Hebert et al, 2005).

Taste buds include three distinct types of mature cells with specific morphological features (Yang et al, 2000; Yee et al, 2001). The functional role of the Type II/Receptor cells is the most clearly understood. They express G-protein-coupled receptors (GPCR) selective for sweet, bitter and umami tastants (Zhang et al, 2003; DeFazio et al, 2006) and downstream signaling molecules such as phospholipase C $\beta 2$ (Rossler et al, 1998) and the non-selective cation channel, TrpM5 (Perez et al, 2002). These effectors drive release of $\mathrm{Ca}^{2+}$ from stores, graded membrane depolarization and subsequent action potentials (reviewed, (Roper, 2007). Receptor cells then secrete ATP via a non-vesicular, pannexin-mediated pathway (Romanov et al, 2007; Huang et al, 2007). Extracellular ATP acts as a transmitter at afferent fibers closely apposed to Receptor cells (Finger et al, 2005), and also secondarily generates $\mathrm{Ca}^{2+}$ responses in Type III/Presynaptic cells (Tomchik et al, 2007). The role of these Type III cells is somewhat less clear. They possess ultrastructurally visible complex synapses, and express typical presynaptic proteins including SNAP25 and voltage gated Ca channels (Yang et al, 2000; Yee et al, 2001). They may be the primary receptor cells for sour tastants (Kataoka et al, 2008) and may also integrate signals from multiple receptor cells (Tomchik et al, 2007). In contrast to the above two classes, the Type I cells are very poorly understood. Type I cells have been termed "glial-like" in part because they express proteins responsible for clearing neurotransmitters: a glutamate transporter, GLAST (Lawton et al, 2000), and an ectonucleotidase, NTPdase2 (Bartel et al, 2006). Their ultrastructural morphology is also suggestive of glia, with sheet-like lateral projections that appear to envelope other cells within the taste bud (Pumplin et al, 1997). Little else is known about their role. Here, we have explored whether Type I cells carry out a key function for which glia are responsible in most of the nervous system: helping to maintain the extracellular 
ionic environment, especially with respect to the $\mathrm{K}^{+}$ions that accumulate when excitable cells fire repeatedly.

To date, expression studies of ROMK have mainly focused on the kidney. The channel was immunocytochemically localized to the apical membranes of renal thick limb and cortical collecting duct epithelial cells (Xu et al, 1997), consistent with earlier reports of mRNA expression using in-situ hybridization (Lee and Hebert, 1995). In rat and human, alternative splicing of ROMK mRNA gives rise to 4 variants (Shuck et al, 1994; Kondo et al, 1996; Beesley et al, 1999) and these are differentially expressed along different segments of the rat nephron (Boim et al, 1995). The ROMK6 mRNA was found to be expressed in excitable cells in brain, eye and pancreas as well as in other tissues such as lung, liver and spleen in the rat (Kondo et al, 1996). In the mouse, the alternatively spliced mRNAs have not been well described, although it has been assumed that they follow the same organization as in the rat. Here, we report the expression of the ROMK2 isoform in a subset of type I/glial-like mouse taste cells.

\section{METHODS}

\section{Animals}

Mice were handled according to the NIH Guidelines for the Care and Use of Laboratory Animals. To collect tissues, mice were killed with $\mathrm{CO}_{2}$ inhalation and cervical dislocation (American Veterinary Medical Association Guidelines on Euthanasia). Alternatively, mice were deeply anesthetized with a ketamine-xylazine cocktail, and perfused intracardially to fix tissues (see below). All procedures were carried out with approval of the Institutional Animal Care and Use Committees, University of Miami or Yale University.

Wild type (C57BL6) or transgenic mice, with enhanced Green Fluorescent Protein (GFP) labeled cells were used. We produced PLC $\beta 2$-GFP mice by pronuclear injection of a construct that included the following $\left(5^{\prime}\right.$ to $\left.3^{\prime}\right): 2.9 \mathrm{~kb}$ of proximal promoter, $\approx 115 \mathrm{bp}$ of $5^{\prime}$ untranslated exon (both from the mouse Plcb2 gene) and coding sequence of GFP. In taste buds of these mice, we showed that GFP is exactly coincident with PLC $\beta 2$ immunocreactivity, i.e. only the Type II/Receptor cells of taste buds are labeled (Kim et al, 2006). GAD-GFP mice were produced by injection of a bacterial artificial chromosome (BAC) that included $60 \mathrm{~kb}$ of upstream sequence and the entire Gadl gene with GFP inserted at the translation initiation site (Chattopadhyaya et al, 2004). In taste buds of this strain, we showed that GFP is expressed only in cells that are immunoreactive for SNAP-25 or 5-HT (i.e. Type III/Presynaptic cells). Approximately $\approx 75 \%$ of Type III cells express GFP (Kim et al, 2006; Tomchik et al, 2007). The background for the PLC $\beta 2-G F P$ mice is mixed C57BL/6 and SJL, while for GAD-GFP mice, it is C57BL/6.

We also crossed the above two strains, PLC $\beta 2$-GFP and GAD-GFP, genotyped for both versions of the GFP transgene, and selected double transgenic i.e. (PLC $\beta 2+\mathrm{GAD})$-GFP mice.

$\mathrm{ROMK}^{-/-}$mice (Lorenz et al, 2002; Lu et al, 2002) were used to validate the specificity of immunostaining for ROMK in taste tissue. Tissue from the knockout mice and from a parallel colony of wild-type mice was fixed and processed in parallel for immunostaining. Both colonies are on a 129/svJ/Black Swiss background.

\section{Tissues and cells for RT-PCR}

RT-PCR was carried out on total RNA from mouse kidney, taste buds and linear-amplified RNA from single, individually collected taste cells. Kidney total RNA was extracted and DNase I digested using Absolutely RNA miniprep kit (Stratagene). Taste buds were 
collected from four taste fields (circumvallate, foliate, fungiform, and palate) as follows.

The tongue was removed and a protease mix containing $1 \mathrm{mg} / \mathrm{ml}$ Collagenase Type A, 2.5 $\mathrm{mg} / \mathrm{ml}$ Dispase (both from Roche Products, Indianapolis, IN) $0.25 \mathrm{mg} / \mathrm{ml}$ Elastase (Worthington, Lakewood, NJ) and $0.5 \mathrm{mg} / \mathrm{ml}$ DNase I (Sigma, St. Louis, MO), dissolved in Tyrode's buffer was injected under the epithelium. Tyrode's buffer was as follows, in mM: $139 \mathrm{NaCl}, 5 \mathrm{KCl}, 2 \mathrm{CaCl}_{2}, 1 \mathrm{MgCl}_{2}, 10$ Hepes, 10 glucose, $10 \mathrm{Na}$ pyruvate, and 5 $\mathrm{NaHCO}_{3}$ ); $\mathrm{pH} 7.2,318-323 \mathrm{mOsm}$. After $20 \mathrm{~min}$, the epithelium was peeled from underlying tissue, and redigested in protease mix for $2 \mathrm{~min}$. It was then rinsed in Tyrode's buffer and incubated for 10 min in $\mathrm{Ca}^{2+} / \mathrm{Mg}^{2+}$-free Tyrode's buffer $\left(\mathrm{CaCl}_{2}\right.$ and $\mathrm{MgCl}_{2}$ replaced with $2 \mathrm{mM}$ each EGTA and BAPTA). Taste buds were identified by GFP fluorescence, collected from the epithelium into glass pipettes ( $80 \mu \mathrm{m}$ inner diameter at the tip) under suction and transferred to lysis buffer. Total RNA was purified and DNase I digested (Absolutely Nanoprep kit, Stratagene).

For RT-PCR on individual taste cells, we first collected circumvallate taste buds as above. We then dissociated the taste buds by very gentle trituration under microscopic examination

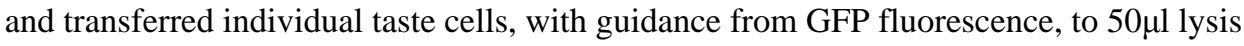
buffer containing $200 \mathrm{ng}$ of polyinosinic acid. RNA was isolated using the Nanoprep kit.

\section{RT-PCR}

First strand cDNA was synthesized using Superscript III (Invitrogen). Each $20 \mu 1$ PCR employed one taste bud-equivalent of cDNA as template. Positive and negative controls were run in parallel from master mixes. We designed PCR primers (Table 1) using sequence from the mouse gene for ROMK (Kcnj1). Each primer pair used for defining splice variants spanned at least one intron to avoid amplifying contaminating genomic DNA. One pair of primers, \#3 and 4, correspond to sequence within the core exon, and was used only with RTPCR on linear-amplified RNA.

The specificity of each reaction was confirmed by sequencing PCR products.

For linear amplification, RNA from individual cells was used as template for reverse transcription and T7 linear RNA amplification using the Message BOOSTER cDNA Synthesis kit for qPCR (MB060124; Epicentre, Madison, WI) as we described previously (DeFazio et al, 2006; Tizzano et al, 2008). For each PCR, 2\% of the cDNA of individual cells was used as template.

Real-Time RT-PCR was carried out using 2x SYBR Green PCR Mix on an iQ iCycler (both BioRad Labs, Hercules, CA). Each $2 \mu 1$ reaction included 5pmole of each primer and cDNA representing 1 tastebud, as described previously (Tizzano et al, 2008). Amplification was at $95^{\circ} \mathrm{C}$ for $15 \mathrm{~s}$ and $59^{\circ} \mathrm{C}$ for $45 \mathrm{~s}$. Melting analysis for each reaction revealed a single peak indicating homogeneous and specific products. We processed three independent samples for each tissue, with triplicate PCRs for every gene analyzed. Copy numbers for each mRNA were estimated from a standard curve using quantified, sequence-validated templates, and analyzed with MyiQ Software (v1.0) (BioRad). PLC $\beta 2$ mRNA, expressed in all Receptor cells, was used as a reference for normalization. Negative (no template) controls were run in parallel to assess specificity and contamination.

\section{Antibodies}

1. Rabbit polyclonal anti-NTPDase2 (\#mN2-36I6 from J. Sévigny at Université Laval, Quebec; used at 1:1000). This antibody was produced against full-length mouse NTPDase2, expressed intramuscularly. Immunoreactivity was demonstrated on transfected COS-7 cells and specificity in taste buds shown by the excellent concordance between mRNA and protein expression patterns (Bartel et al, 2006). 
2. Rabbit polyclonal, affinity-purified anti-Claudin-8 (\#40-0700Z, Invitrogen; used at 1:100) was raised against a 20-mer peptide derived from the identical C-termini of mouse and rat Claudin-8 (mouse amino acid \# 206-225, NP_061248). The antibody recognizes the expected $\approx 30 \mathrm{kDa}$ protein (manufacturer's data). Specificity in taste tissue was demonstrated through the use of blocking peptide and by co-localization with villin, a marker of tight junctions (Michlig et al, 2007).

3. Polyclonal affinity-purified goat anti-ChrgA (\#sc-1488, Santa Cruz Biotechnology, CA; used at 1:200) was raised against a 28-mer C-terminal peptide, identical in human and mouse (human amino acid \#430-457; NP_001266). Specificity was demonstrated via reactivity in enteroendocrine cells and antigenic peptide block (Rozengurt et al, 2006) and for mouse taste buds, by concordance in the expression patterns of mRNA and immunofluorescence and via a preabsorption control (Dvoryanchikov et al, 2007).

4. Polyclonal affinity-purified anti-PLC 32 (\#SC-206, Santa Cruz Biotechnology; used at 1:2000) was raised in rabbits against a C-terminal peptide (amino acid \#1170-1181, human, EAW92403) and recognizes a single $120 \mathrm{kDa}$ band on immunoblots of macrophages (manufacturer's data). We showed that immunofluorescence is strong in taste buds of wild type mice and completely lacking in PLC $\beta 2^{-/-}$mice (Trubey et al, 2006).

5. Polyclonal affinity-purified anti-ROMK (\#APC-001, lot \#AN-10; Alomone Labs, Jerusalem) was raised in rabbit against a fusion protein that included the $\mathrm{C}$-terminal 50 amino acids of rat/mouse ROMK/Kir1.1 (rat amino acid \#342-391, P35560).

The ROMK-Gst-fusion protein antigen, included with this antibody was used as a preincubation control (described below). The specificity of this antibody was shown in rat kidney, where signal is localized to the luminal surface of renal tubule segments known to express ROMK, and was eliminated both by preincubation with the fusion protein antigen (Mennitt et al, 2000), and in renal tubules of $\mathrm{ROMK}^{-1-}$ mice (Lin et al, 2004a).

Secondary antibodies were from Invitrogen: goat anti-rabbit IgG-Alexa 594 (\#A11012; used at 1:1000); donkey anti-rabbit IgG-Alexa 594 (\#A21207; used at 1:1000); goat anti-rabbit IgG-HRP conjugate (\#T20925; used at 1:500) or from Jackson Immunoresearch (West Grove, PA): donkey anti-goat Cy5 (\#705-175-147; used at 1:500). The specificity of each secondary antibody was confirmed by incubating some tissue sections with primary antibody omitted. No fluorescent signal was detected for any of these secondary antibodies under the conditions used throughout this study.

\section{Immunostaining}

Immunohistochemistry for ROMK on tissue sections was performed as follows. Mice were transcardially perfused with fixative: $4 \%$ paraformaldehyde in Phosphate Buffered Saline (PBS; in mM: $154 \mathrm{NaCl}, 1 \mathrm{KH}_{2} \mathrm{PO}_{4}, 3 \mathrm{Na}_{2} \mathrm{HPO}_{4} ; \mathrm{pH} 7.4$ ). Kidney, palate, circumvallate and foliate taste papillae and the anterior tongue (for fungiform taste buds) were dissected out and postfixed for 1 hour at $4^{\circ} \mathrm{C}$ in the same fixative. Tissues were washed in PBS, cryoprotected in $30 \%$ sucrose in PBS overnight at $4^{\circ} \mathrm{C}$, embedded in OCT medium and cryosectioned at $20 \mu \mathrm{m}$. Tissue sections were permeabilized for 15 minutes (1\% Triton $\mathrm{X}-100$ in PBS). Nonspecific binding of antibodies was blocked with PBS containing $0.3 \%$ Triton X-100, $2 \%$ bovine serum albumin (BSA) and $2 \%$ serum (either goat or donkey to match the secondary antibody) for 1.5 hours at room temperature. After this, sections were incubated in anti-ROMK (diluted 1:100), overnight at room temperature. After thorough washing in PBS, sections were incubated with fluorescent secondary antibodies at room temperature for 2 hours. 
In some cases (Figures 4A and 5), the immunofluorescence signal was amplified with tyramide. For this, anti-ROMK was applied at 1:500 and was followed by goat anti-rabbit IgG-peroxidase as the secondary antibody (see above). Sections were reacted with peroxidase substrate, Alexa 594-tyramide (T20925, Invitrogen; diluted 1:100). We observed very similar localization and intensity of the ROMK signal with either detection method.

As a negative control, anti-ROMK was pre-incubated with the fusion protein antigen (Alomone Labs; supplied with anti-ROMK) in PBS with 1\% BSA, $0.025 \% \mathrm{NaN}_{3}$ ) for 1 hour at room temperature at a 14:1 molar ratio of antigen to antibody. A parallel incubation was also set up with anti-ROMK, diluted similarly but without the control antigen, and was processed identically. The solutions were then centrifuged for 5 minutes at 10,000xg to pellet antigen-antibody complexes, and the supernatant was used in place of the primary antibody. Pre-incubation with the antigen eliminated all immuno-fluorescence detected in renal tubules and in taste buds of wild-type mice.

To carry out immunostaining with two rabbit-derived primary antibodies, we pre-labeled one of the antibodies (e.g. anti-NTPdase 2 or anti-Claudin-8). For direct labeling, the antibody was pre-incubated for 1 hour with Alexa 647-conjugated anti-rabbit Fab fragments (Zenon rabbit IgG labeling kit, \#Z-25308, Invitrogen) exactly following the manufacturer's instructions. Excess Fab fragments were neutralized by addition of a nonspecific rabbit IgG. Immunostaining for the unlabeled antibody, including binding primary and secondary antibodies was carried out as above. Next, sections were washed in PBS, incubated with the pre-labeled primary antibody (final dilution, 1:500) for $80 \mathrm{~min}$, washed in PBS, post-fixed in $4 \%$ PFA for 15 min, and washed in PBS before mounting.

\section{Microscopy}

Fluorescent and brightfield (with Nomarski differential contrast) micrographs were captured either on a Zeiss Axioplan microscope (Figure 3A, B), using Zeiss Axiovision v.3.0 software or on a Zeiss LSM510 confocal Axiovert 200M microscope (all other images). Confocal images were captured with a Zeiss plan-apochromat 63x/1.4 NA lens, with 488, 543, and 633nm laser lines, for GFP, Alexa Fluor 594, and Alexa Fluor 647 detection, respectively. Pinhole size was set to acquire 1-1.4 $\mu \mathrm{m}$ optical slices. Control and experimental sections were imaged in parallel and under identical settings. Brightness and contrast were adjusted, in parallel for experimental and control images, in Photoshop (Adobe Systems, San Jose CA).

\section{RESULTS}

\section{ROMK splice variants in mouse}

Although many recent studies have focused on mouse kidney, an explicit definition of alternative mRNAs for the mouse has not been published. Therefore, we aligned genomic sequences for the ROMK gene, Kcnj1, from rat (AC127149) and mouse (AC141646) to define kcnj1 exons in the mouse. By inference from expressed sequences in the rat (AF081365, S69385, AF081367 and AF081368), we predicted the sequence boundaries of the four alternatively spliced mRNAs, ROMK1, 2, 3, and 6 in the mouse (Figure 1A). We confirmed that ROMK mRNA in mouse kidney exists in each of these variants by RT-PCR with isoform-specific pairs of PCR primers (Figure 1A, Table 1). As expected, mRNA from mouse kidney yielded PCR products of the expected size for all four splice variants (Figure 1B, Table 1). Of these, ROMK1 and ROMK2 appeared more abundant than ROMK3 and ROMK6. We subjected these PCR products, representing the 5' ends of the transcripts, to DNA sequencing, which confirmed their identity. The predicted amino acid sequences of ROMK2 and ROMK6 in the mouse were identical to each other, just as in the rat (Figure 
1A). The protein sequence of ROMK1 and ROMK3 each has an N-terminal extension derived from translation of part of an upstream exon. In summary, mouse ROMK isoforms are very similar to those previously defined in the rat. Thus, we have used the nomenclature previously established for rat (Kondo et al, 1996; Beesley et al, 1999).

\section{ROMK mRNA in taste buds}

We analyzed RNA samples from taste buds of four taste fields (circumvallate, foliate and fungiform papillae as well as palate) along with non-taste lingual epithelium. Only ROMK2 was seen in any of the lingual samples that we tested (Figure 2A). To compare quantitative differences in mRNA levels for ROMK2, we conducted real-time RT-PCR on taste samples. Because isolated taste buds include significant amounts of surrounding non-sensory epithelial cells, we selected a taste bud-specific mRNA, PLC $\beta 2$, for normalizing mRNA copy numbers. On average, ROMK2 mRNA was present in vallate at 8-fold higher concentration than in palate and 25-fold higher than in fungiform (Figure 2B). Foliate taste buds express ROMK 2 mRNA at a level intermediate between vallate and palate, consistent with their mixed innervation (cranial nerves VII and IX). In contrast, mRNA for PLC $\beta 2$ was found at relatively similar levels in all taste buds, varying at most 2-fold across taste buds from different oral regions (Figure 2C). Neither ROMK2 nor PLC $\beta 2$ were significantly detected in non-taste epithelial samples (Figure 2B, C).

\section{ROMK is immunohistochemically detected in taste tissue}

We then asked if we could detect expression of the ROMK protein by immunofluorescence microscopy. Cryosections of vallate taste papillae were subjected to immunohistochemical staining for ROMK. We found that ROMK was detected in all vallate taste buds, and that staining appeared most prominently near the apical tips of taste buds (Figure 3A, B). The apical tips of taste cells and the "pore material" in the taste pore may bind antibodies nonspecifically, yielding artifactual staining that is not derived from the antigen under consideration (our unpublished observations). Thus, we applied the rigorous test of examining wild-type and ROMK knockout tissues, processed in parallel. As expected, wildtype kidney showed strong immunofluorescence (Figure 3C) in the apical membranes of renal tubules, especially in the medullary rays and cross-sectioned tubules in the cortex $(\mathrm{Xu}$ et al, 1997) whereas the knockout kidney (Figure 3D) completely lacked fluorescence in kidney tubules, just as previously reported (Lu et al, 2002). Similarly, circumvallate papillae from ROMK -/- mice were devoid of the apically concentrated immunofluorescence, while taste papillae from wild type mice processed in parallel showed a strong apical signal (Figure 3E, F). As an additional control, we pre-incubated the primary anti-ROMK with the antigenic fusion protein supplied by the manufacturer. In this case, there was complete absence of fluorescence signal in taste buds (not shown). Finally, parallel sections for which primary antibody was omitted during incubations also were devoid of fluorescent signal in taste buds (not shown). Thus, we conclude that the fluorescence signal detected in taste cells derives from expression of ROMK protein.

\section{ROMK is expressed differentially across taste fields and cell-types}

Mature cells in taste buds fall into three morphological and functional classes (Yee et al, 2001; DeFazio et al, 2006; Clapp et al, 2006). We have previously established two mouse strains in each of which, GFP expression faithfully illuminates one taste cell type: PLC 32 GFP for Type II/Receptor cells and GAD-GFP for most Type III/Presynaptic cells (Kim et al, 2006; Tomchik et al, 2007). We immunostained taste tissues from these transgenic mice for ROMK, using Alexa 594-conjugated secondary antibody, to allow us to identify which taste cell type(s) express ROMK. After imaging the tissue under a confocal microscope, we found that ROMK was not co-expressed with GFP in either transgenic strain and in any of the taste fields tested (Figure 4A-H). That is, ROMK is expressed in taste cells that are 
neither Type II nor Type III. We also noted that ROMK was found in fewer cells in palatal taste buds compared to vallate and foliate taste buds (Figure 4C, G). Fungiform taste buds (Figure 4D, H) almost completely lacked ROMK-expressing cells, an observation that is consistent with our qRT-PCR data described above.

Mature mammalian taste cells are bipolar, fusiform, with a rather narrow apical process (Pumplin et al, 1997; Yee et al, 2001). Thus, in a conventional vertical section, only limited profiles of the tips of cells are visible. For a better a view of whether ROMK is co-expressed with GFP in either transgenic strain, we immunostained cross-sections of vallate taste buds and imaged them with confocal microscopy. Optical sections, in which the apical ends of taste buds were visible, showed ROMK at the tips of cells. ROMK-positive cells were clearly distinct from GFP-positive cells, and appeared to interdigitate between them (Fig. 5). This orientation allowed for better estimation of the number of ROMK positive cells in taste buds. We counted all ROMK-immunostained taste cells visible in representative crosssections of vallate papillae from each transgenic strain. We also counted all the GFP-labeled cells in those same optical sections (a total of 24 taste buds for PLC $\beta 2$-GFP and 44 taste buds for GAD-GFP in three separate experiments). The average number of ROMKexpressing cells (mean \pm s.e.m) in each vallate taste bud was $7.3+/-0.3$ ( $\mathrm{n}=68$ taste buds). This was intermediate between the average number of PLC $\beta 2$-GFP cells $(8.8+/-0.6, \mathrm{n}=24$ taste buds) and GAD-GFP cells ( $4.8+/-0.3, \mathrm{n}=44$ taste buds). Because ROMK immunostaining was limited to the apical tips of taste cells, only a limited number of $1 \mu \mathrm{m}$ optical sections contained stained cells that could be confidently identified and counted. Of the 481 cells we counted as immunostained for ROMK, only 1 appeared to also express GFP (it was in the GAD-GFP strain). It should be noted that because we counted only brightly fluorescent cells, the above are minimum estimates. For instance, immature or dying cells may express lower concentrations of the marker proteins and would not be counted. Thus, the total numbers of cells counted is lower than is achievable by electron microscopy, or simply counting labeled nuclei in light microscopy.

\section{ROMK is in Type I/glial-like taste cells}

Based on the above result that ROMK is expressed in neither Type II nor Type III cells, we asked if ROMK protein in taste buds is expressed in Type I/glial-like cells. Because Type I cells have been studied relatively little to date, we used three methods to address this question: immunostaining for a Type I cell marker, RT-PCR on amplified RNA (aRNA) from taste cells, and direct RT-PCR on individual taste cells.

For immunostaining, we used a well-characterized and previously validated antibody against NTPDase2, a marker for Type I taste cells (Bartel et al., 2006). We asked if the ROMK protein was co-expressed in the same cells with NTPDase2. We found that in virtually all cases, ROMK immunostaining was detected in cells that were also immuno-positive for NTPDase2 (Figure 6A, B, C). Although both are integral membrane proteins of the plasma membrane, NTPDase2, unlike ROMK, is found over the entire cell surface - basolateral and apical regions alike. Almost all ROMK-positive cells were also NTPDase2-positive gliallike cells (190 out of 191 cells).

We did not attempt to estimate the numbers of Type I cells: the task is difficult owing to their convoluted morphology and ensheathing of other cells in the taste bud. Nevertheless, it was apparent that not all NTPDase2-positive cells expressed ROMK (arrowhead, Figure 6, E). This is consistent with our single-cell RT-PCR results (see below). Using three labels (GFP, Alexa 594 and Alexa 647), we observed in taste tissue from PLC $\beta 2-G F P$ and GADGFP mice, that ROMK and NTPDase 2 colocalized with each other but never with GFP (Figure 6D, E). 
To analyze ROMK mRNA in individual taste cells, we initially surveyed a set of cells for which we previously profiled gene expression patterns (DeFazio et al., 2006; Huang et al., 2007). Well-isolated single cells had been collected and subjected to linear amplification of RNA followed by cDNA synthesis. Small fractions of each amplified cell sample had been subjected to RT-PCR for PLC 32 , SNAP25 and NTPDase2 in order to assign each original cell to a unique category - Types II, III and I, respectively. We selected 4 Type II/Receptor cells, 4 Type III/Presynaptic cells and 13 Type I/glial-like cells for the present analysis. We asked which of these cell-type markers associated with ROMK and found that ROMK expression was detected in 3 of 13 of the NTPDase2-expressing (Glial-like) cells but not in any PLC $\beta 2$-expressing (Receptor) or SNAP-25-expressing (Presynaptic) cells. From this analysis, two representative cells of each type are shown in Figure 8A. Although the number of cells analyzed is relatively small, the result is qualitatively consistent with our immunostaining data above, that ROMK is expressed exclusively in Type I/glial-like taste cells. Because of non-linearity in the RNA amplification steps, RT-PCR from aRNA templates may sometimes fail to reveal mRNAs expressed at low copy number in the original tissue. Thus, we considered that ROMK expression in only a small fraction of Type I cells ( 3 of 13) could be an underestimate.

For a more definitive evaluation of the incidence of ROMK expression in Type I cells, we extended the single-cell RT-PCR analysis with a fresh taste cell isolation. We enriched our cell collection for Type I cells in the following manner. We cross-bred PLC $\beta 2-G F P$ and GAD-GFP mice, and identified double transgenic mice by genotyping. In these mice, we expected that all Type II plus most Type III taste cells should be GFP-labeled (validated below in the next section). We then isolated vallate taste buds (Figure 8B) from these double transgenic mice using an improved isolation procedure that we recently developed (see Methods) and found, as expected, that very large numbers of cells were GFP-labeled. We dissociated these taste buds, and harvested 20 single cells that lacked GFP (Figure 8C, D, E). We then isolated total RNA from each cell, and used $10 \%$ of each cell's cDNA as template for PCR for NTPDase2. Of these 20 cells, 11 cells yielded a RT-PCR product for NTPDase2. Next, 25\% of the cDNA from each NTPDase2-positive cells served as template to detect ROMK by PCR. In this direct RT-PCR analysis, we found that 10 of 11 NTPDase2-expressing (i.e. Type I) cells also expressed ROMK. Cells that did not express NTPDase 2 were not analyzed further.

\section{Validating double transgenic (PLC+GAD)-GFP mice}

Vallate papillae from the double transgenic mice were immunostained for PLC $\beta 2$, a marker for all Type II/Receptor cells (DeFazio et al, 2006) and chromogranin A, a marker for all Type III/Presynaptic cells (Dvoryanchikov et al, 2007). To detect each of these in addition to GFP, we used secondary antibodies conjugated to Alexa 594 and Cy5 respectively. Pairwise overlay of GFP with each of the antibodies (Figure 8A, B, C) suggested that nearly all GFP-expressing cells were positive for either PLC $\beta 2$ or Chromogranin A (Figure 8D). Very few cells showed evidence of GFP alone. A few Chromogranin A-positive cells were detected that lacked GFP (Figure 8C). This is consistent with our earlier demonstration that in GAD-GFP taste buds, about 75\% of Presynaptic cells are GFP-positive (Tomchik et al, 2007). Indeed, we have recently shown that the GFP-lacking Presynaptic cells form a discrete sub-class with distinct functional properties (Roberts et al, 2009). Thus in summary, we infer that GFP-lacking cells in this double-transgenic mouse should include the few GFP-negative Presynaptic cells, plus a large number of Type I cells. The (PLC $\beta 2+G A D)$ GFP mouse tissue thus serves as an effective tool to enrich for Type I cells in the single cell isolation procedure. In spite of the fragile nature of Type I cells, with their thin cytoplasmic lamellae, we were able to detect NTPDase 2 mRNA in 11 of 20 GFP-lacking cells from vallate taste buds. 


\section{ROMK is localized at and above gap junctions}

Tight junctions are located at the apical ends of taste cells, with only microvilli and other thin projections extending above them (Murray, 1993). We examined the localization of ROMK relative to apical tight junctions using immunofluorescence against Claudin-8, recently demonstrated to be a component of tight junctions in taste buds (Michlig et al, 2007). The pattern of Claudin- 8 immunoreactivity In vallate taste buds was identical to an earlier report (Michlig et al, 2007), with faint cytoplasmic fluorescence in some cells, bright ring-like structures near the taste pore (not shown). In taste buds from a GAD-GFP mouse, we saw that soluble GFP protein was seen exclusively below the tight junction (Figure 9A, $\mathrm{C}, \mathrm{E}$ ) just as previously reported (Michlig et al, 2007). In contrast, ROMK immunostaining clearly extended through the level of the Claudin-8 labeled tight junctions (Figure 9B, D, F). In some instances, slender projections immunostained for ROMK could be seen well above the tight junctions (e.g. Figure 9B, asterisk). These bear a remarkable resemblance to apical processes on Type I cells, seen in electron micrographs (Murray, 1993).

\section{DISCUSSION}

By RT-PCR and immunohistochemistry, we show that a single alternative splicing variant of the Kcnj1 gene, ROMK2, is expressed in taste buds in vallate and foliate papillae and in the palate. The protein is strongly localized to the apical region of a majority of Type I/glial like cells and is lacking from both Type II/Receptor cells and Type III/Presynaptic cells. The specificity of these cellular and subcellular assignments is supported by the excellent concordance between our single-cell RT-PCR and confocal immunohistochemical results, as well as the complete loss of signal in taste buds of ROMK knockout mice. ROMK was reported to be expressed in duct cells of submandibular gland (Liu et al, 1999). In our immunohistochemical experiments, we too observed apical staining in salivary duct epithelial cells (not shown).

Detailed analyses on Kir1.1/ROMK mRNA in rat and human kidney are published. In both species, ROMK transcripts are spliced to yield alternative mRNAs (ROMK1, 2, 3 and 6), that vary at both ends. Variability at the $3^{\prime}$ end is limited to the $3^{\prime}$-untranslated region and does not alter protein sequence (Boim et al, 1995). Alternative short exons at the $5^{\prime}$ end produce ROMK proteins that vary upto 27 amino acids at the N-termini, and exhibit distinct functional properties (Kondo et al, 1996; Beesley et al, 1999). Yet, although recent work has focused on genetically modified mice, alternatively spliced ROMK mRNAs are not well documented for mice. Similar to results in the rat, we detected all four splice variants of ROMK in mouse kidney, ROMK1, ROMK2, ROMK3 and ROMK6. As in rat, ROMK2 and ROMK6 mRNA are predicted to translate to identical amino acid sequences, while ROMK1 and ROMK3 have extended N-termini. Our analysis is consistent with a recent report that described ROMK1 and 2 isoforms in mouse kidney tubules (Fodstad et al, 2009). Our RTPCR data show that only one splice variant, ROMK2, is expressed in taste buds, and in a highly taste-selective manner.

The function of ROMK channels is best described in the kidney. ROMK forms two apical $\mathrm{K}$ channels (of 70pS and 35pS conductance) that play an essential role in $\mathrm{NaCl}$ reabsorption and $\mathrm{K}^{+}$secretion in the mammalian nephron (reviewed, (Choe et al, 1997; Palmer, 1999). $\mathrm{K}^{+}$recycling via apical ROMK generates a lumen-positive potential, which is a driving force for $\mathrm{Na}^{+}$and $\mathrm{Cl}^{-}$reabsorption via the Na-K-Cl-Cotransporter (NKCC) in the thick ascending limb. ROMK channels also provide the major secretory pathway for regulated $\mathrm{K}^{+}$ excretion by the late nephron. The surface expression of ROMK channels in principal cells is regulated by dietary $\mathrm{K}^{+}$intake. High dietary $\mathrm{K}^{+}$increases the number of active ROMK channels thereby enhancing the $\mathrm{K}^{+}$-secretory capacity of the collecting tubule (Hebert et al, 2005; Wang and Giebisch, 2008). In humans, loss-of-function mutations in ROMK cause 
neonatal Bartter's syndrome, characterized by salt wasting and hypokalemia (Simon et al, 1996). ROMK knockout mice exhibit a very similar phenotype (Lorenz et al, 2002; Lu et al, 2002). ROMK, expressed constitutively, works in conjunction with flow-dependent expression of $\mathrm{BK}$ channels to achieve $\mathrm{K}^{+}$balance in the nephron through selective secretion (Sansom and Welling, 2007). In addition to being regulated by ATP, ROMK is gated by internal $\mathrm{pH}$ and external $\mathrm{K}^{+}$concentration (Doi et al, 1996; Choe et al, 1997; Sackin et al, 2007).

Although ROMK is expressed in a few non-renal cells, its other functions are not extensively explored. There are suggestions that ROMK (Kir1.1), along with other $\mathrm{pH}$ sensitive inward-rectifiers (Kir2.3, Kir4.1, and Kir5.1) may serve as $\mathrm{CO}_{2} / \mathrm{H}^{+}$sensors in the central nervous system (Zhu et al, 2000; Jiang et al, 2001). ROMK is expressed in the brain, particularly in the chemosensory areas of the medulla oblongata (Kenna et al, 1994; Yamamoto et al, 2008) and ROMK channel blockers inhibit $\mathrm{CO}_{2}$-evoked medullary neuronal activity (Schultz et al, 2003).

In the case of acid taste responses, a drop in taste cell cytoplasmic $\mathrm{pH}$ is an essential trigger for evoking taste cell $\mathrm{Ca}^{2+}$ responses and activity in afferent nerves (Lyall et al, 2001; Huang et al, 2008). Several ion channels have been considered as candidate chemosensors, including two-pore domain $\mathrm{K}$ channels that are inhibited by cytoplasmic acidification (Richter et al, 2004; Lin et al, 2004b). In contrast, the PKD1L3/PKD2L1 heterodimeric channel, proposed as the sour taste receptor (Huang et al, 2006; Ishimaru et al, 2006), detects primarily extracellular protons and is insensitive to a drop in cytoplasmic $\mathrm{pH}$. Among cells of taste buds, Type III/Presynaptic cells are essential for detecting acidic stimuli (Huang et al, 2006) and produce robust $\mathrm{Ca}^{2+}$ responses to apically applied acid tastants (Tomchik et al, 2007). This does not preclude the involvement of other cell types in detecting sour taste. In $C$. elegans, acid detection requires the concurrent involvement of acid-sensitive ion channels in both chemosensory neurons and attendant peripheral glial cells (Wang et al, 2008). By analogy, because channel activity is pH-dependent (McNicholas et al, 1998), ROMK may be an excellent candidate for contributing to sour taste.

Other roles for inwardly-rectifying $\mathrm{K}^{+}$channels have been put forward. One example is "spatial $\mathrm{K}^{+}$buffering", whereby glial cells in the brain and retina absorb $\mathrm{K}^{+}$that has built up around active neurons, and secrete $\mathrm{K}^{+}$to a low concentration extracellular sink in a distant location (Kofuji et al, 2002; Butt and Kalsi, 2006). Glia accomplish this by expressing Kir channels of varying conductance and gating properties and differentially localizing them to specific membrane domains, resulting in a directed flow of $\mathrm{K}^{+}$ions into the cell in one direction and out in another. In the kidney, ROMK essentially performs the same function. By being localized only to the apical membrane, ROMK permits $\mathrm{K}^{+}$flux in one direction, into the tubule lumen.

We found ROMK to be expressed in glial-like cells inside taste buds. As in the thick ascending limb and principal cells of renal tubules, ROMK in glial-like taste cells exhibits a highly polarized distribution, being found only at the apical membrane. We suggest that, in analogy to glia, ROMK in type I taste cells, in conjunction with other $\mathrm{K}^{+}$channels, acts to regulate $\mathrm{K}^{+}$in the extracellular space around excitable Receptor and Presynaptic cells. The role of ROMK in this scenario would be to transport excess $\mathrm{K}^{+}$out of the taste bud by secretion through the apical pore (Figure 10). Type I cells are reported to end in relatively long processes that can extend into the taste pore (Murray, 1993). Such expansions of cell surface above the tight junction would help in $\mathrm{K}^{+}$extrusion (see Fig. 9B). Although a ROMK knockout mouse exists, it exhibits severe salt wasting, hypokalemia and other 
systemic deficits (Lorenz et al, 2002; Lu et al, 2002). Thus, it would be difficult to use this global knockout to evaluate the role of ROMK in taste buds.

The virtual absence of ROMK in fungiform taste buds may suggest that other, $\mathrm{K}$ channels may subsume the buffering role in these taste buds. For instance, the 2-pore domain $\mathrm{K}$ channel, TWIK-1 (Kcnk1), known to be expressed in mouse taste buds (Richter et al, 2004), participates in potassium secretion in the kidney alongside ROMK (Cluzeaud et al, 1998). TWIK-1 is a regulator of extracellular $\mathrm{K}^{+}$homeostasis in non-sensory (strial marginal) cells of the inner ear (Nicolas et al, 2003). We note that the cystic fibrosis transmembrane conductance regulator (CFTR), which is functionally associated with ROMK in renal tubules is also reported to be expressed in some non-Type II cells in rat taste buds (Merigo et al, 2008).

$\mathrm{K}$ channels in taste buds fulfill a number of additional roles. In most cells, $\mathrm{K}$ leak channels serve to set resting membrane potential. This function in taste cells, along with sensitivity to acidic conditions has been attributed by $\mathrm{Ca}^{2+}$ imaging and patch clamp evidence to two-pore domain K leak channels (Richter et al, 2004; Lin et al, 2004b; Liu et al, 2005; Ohmoto et al, 2006). Similarly, voltage-gated delayed rectifier Shaker-type channels including Kv1.5 were shown to underlie recovery from strong depolarization and action potentials (Liu et al, 2005). Expression data (RT-PCR, immunohistochemistry and in situ hybridization) have shown the presence of additional voltage-gated K channels including Kcnq1 and Kcnh2 in many taste cells (Ohmoto et al, 2006; Wang et al, 2009).

\section{Acknowledgments}

Grant support: National Institutes of Health/NIDCD grant R01DC006308 (to N.C.)

We thank Dr. Stephen Roper (University of Miami) for helpful discussions throughout, and help with microscopy and Dr. George McNamara, Analytical Imaging Core Facility, University of Miami, for training and assistance with confocal microscopy. We acknowledge the support of NIH/NIDCD grant R01DC006308 (to NC) for these studies.

\section{References}

Bartel DL, Sullivan SL, Lavoie EG, Sevigny J, Finger TE. Nucleoside triphosphate diphosphohydrolase-2 is the ecto-ATPase of type I cells in taste buds. J Comp Neurol. 2006; 497(1):1-12. [PubMed: 16680780]

Beesley AH, Ortega B, White SJ. Splicing of a retained intron within ROMK K+ channel RNA generates a novel set of isoforms in rat kidney. Am J Physiol. 1999; 276(3 Pt 1):C585-C592. [PubMed: 10069985]

Boim MA, Ho K, Shuck ME, Bienkowski MJ, Block JH, Slightom JL, Yang Y, Brenner BM, Hebert SC. ROMK inwardly rectifying ATP-sensitive K+ channel. II. Cloning and distribution of alternative forms. Am J Physiol. 1995; 268(6 Pt 2):F1132-F1140. [PubMed: 7611454]

Boughter JD Jr, Pumplin DW, Yu C, Christy RC, Smith DV. Differential expression of alphagustducin in taste bud populations of the rat and hamster. J Neurosci. 1997; 17(8):2852-8. [PubMed: 9092606]

Butt AM, Kalsi A. Inwardly rectifying potassium channels (Kir) in central nervous system glia: a special role for Kir4.1 in glial functions. J Cell Mol Med. 2006; 10(1):33-44. [PubMed: 16563220]

Chattopadhyaya B, Di CG, Higashiyama H, Knott GW, Kuhlman SJ, Welker E, Huang ZJ. Experience and activity-dependent maturation of perisomatic GABAergic innervation in primary visual cortex during a postnatal critical period. J Neurosci. 2004; 24(43):9598-611. [PubMed: 15509747]

Choe H, Zhou H, Palmer LG, Sackin H. A conserved cytoplasmic region of ROMK modulates pH sensitivity, conductance, and gating. Am J Physiol. 1997; 273(4 Pt 2):F516-F529. [PubMed: 9362329] 
Clapp TR, Medler KF, Damak S, Margolskee RF, Kinnamon SC. Mouse taste cells with G proteincoupled taste receptors lack voltage-gated calcium channels and SNAP-25. BMC Biol. 2006; 4:7. [PubMed: 16573824]

Cluzeaud F, Reyes R, Escoubet B, Fay M, Lazdunski M, Bonvalet JP, Lesage F, Farman N. Expression of TWIK-1, a novel weakly inward rectifying potassium channel in rat kidney. Am J Physiol Cell Physiol. 1998; 275(6):C1602-C1609.

DeFazio RA, Dvoryanchikov G, Maruyama Y, Kim JW, Pereira E, Roper SD, Chaudhari N. Separate populations of receptor cells and presynaptic cells in mouse taste buds. J Neurosci. 2006; 26(15): 3971-80. [PubMed: 16611813]

Deutsch C. Potassium channel ontogeny. Annu Rev Physiol. 2002; 64:19-46. [PubMed: 11826262]

Doi T, Fakler B, Schultz JH, Schulte U, Brandle U, Weidemann S, Zenner HP, Lang F, Ruppersberg JP. Extracellular $\mathrm{K}+$ and intracellular $\mathrm{pH}$ allosterically regulate renal Kir1.1 channels. J Biol Chem. 1996; 271(29):17261-6. [PubMed: 8663367]

Dvoryanchikov G, Tomchik SM, Chaudhari N. Biogenic amine synthesis and uptake in rodent taste buds. J Comp Neurol. 2007; 505(3):302-13. [PubMed: 17879273]

Finger TE, Danilova V, Barrows J, Bartel DL, Vigers AJ, Stone L, Hellekant G, Kinnamon SC. ATP signaling is crucial for communication from taste buds to gustatory nerves. Science. 2005; 310(5753):1495-9. [PubMed: 16322458]

Fodstad H, Gonzalez-Rodriguez E, Bron S, Gaeggeler H, Guisan B, Rossier BC, Horisberger JD. Effects of mineralocorticoid and $\mathrm{K}+$ concentration on $\mathrm{K}+$ secretion and ROMK channel expression in a mouse cortical collecting duct cell line. Am J Physiol Renal Physiol. 2009; 296(5):F966-F975. [PubMed: 19297448]

Gao N, Lu M, Echeverri F, Laita B, Kalabat D, Williams ME, Hevezi P, Zlotnik A, Moyer BD. Voltage-gated sodium channels in taste bud cells. BMC Neurosci. 2009; 10:20. [PubMed: 19284629]

Hebert SC, Desir G, Giebisch G, Wang W. Molecular diversity and regulation of renal potassium channels. Physiol Rev. 2005; 85(1):319-71. [PubMed: 15618483]

Ho K, Nichols CG, Lederer WJ, Lytton J, Vassilev PM, Kanazirska MV, Hebert SC. Cloning and expression of an inwardly rectifying ATP-regulated potassium channel. Nature. 1993; 362(6415): 31-8. [PubMed: 7680431]

Huang AL, Chen X, Hoon MA, Chandrashekar J, Guo W, Trankner D, Ryba NJ, Zuker CS. The cells and logic for mammalian sour taste detection. Nature. 2006; 442(7105):934-8. [PubMed: 16929298]

Huang YA, Maruyama Y, Stimac R, Roper SD. Presynaptic (Type III) cells in mouse taste buds sense sour (acid) taste. J Physiol. 2008; 586(Pt 12):2903-12. [PubMed: 18420705]

Huang YJ, Maruyama Y, Dvoryanchikov G, Pereira E, Chaudhari N, Roper SD. The role of pannexin 1 hemichannels in ATP release and cell-cell communication in mouse taste buds. Proc Natl Acad Sci U S A. 2007; 104(15):6436-41. [PubMed: 17389364]

Ishimaru Y, Inada H, Kubota M, Zhuang H, Tominaga M, Matsunami H. Transient receptor potential family members PKD1L3 and PKD2L1 form a candidate sour taste receptor. Proc Natl Acad Sci U S A. 2006; 103(33):12569-74. [PubMed: 16891422]

Jiang C, Xu H, Cui N, Wu J. An alternative approach to the identification of respiratory central chemoreceptors in the brainstem. Respir Physiol. 2001; 129(1-2):141-57. [PubMed: 11738651]

Kataoka S, Yang R, Ishimaru Y, Matsunami H, Sevigny J, Kinnamon JC, Finger TE. The candidate sour taste receptor, PKD2L1, is expressed by type III taste cells in the mouse. Chem Senses. 2008; 33(3):243-54. [PubMed: 18156604]

Kenna S, Roper J, Ho K, Hebert S, Ashcroft SJ, Ashcroft FM. Differential expression of the inwardlyrectifying K-channel ROMK1 in rat brain. Brain Res Mol Brain Res. 1994; 24(1-4):353-6. [PubMed: 7968375]

Kim JW, Roberts C, Maruyama Y, Berg S, Roper S, Chaudhari N. Faithful expression of GFP from the PLCbeta2 promoter in a functional class of taste receptor cells. Chem Senses. 2006; 31(3): 213-9. [PubMed: 16394244] 
Kofuji P, Biedermann B, Siddharthan V, Raap M, Iandiev I, Milenkovic I, Thomzig A, Veh RW, Bringmann A, Reichenbach A. Kir potassium channel subunit expression in retinal glial cells: implications for spatial potassium buffering. Glia. 2002; 39(3):292-303. [PubMed: 12203395]

Kondo C, Isomoto S, Matsumoto S, Yamada M, Horio Y, Yamashita S, Takemura-Kameda K, Matsuzawa Y, Kurachi Y. Cloning and functional expression of a novel isoform of ROMK inwardly rectifying ATP-dependent K+ channel, ROMK6 (Kir1.1f). FEBS Lett. 1996; 399(1-2): 122-6. [PubMed: 8980134]

Kubo Y, Adelman JP, Clapham DE, Jan LY, Karschin A, Kurachi Y, Lazdunski M, Nichols CG, Seino $S$, Vandenberg CA. International Union of Pharmacology. LIV. Nomenclature and molecular relationships of inwardly rectifying potassium channels. Pharmacol Rev. 2005; 57(4):509-26. [PubMed: 16382105]

Kubo Y, Baldwin TJ, Jan YN, Jan LY. Primary structure and functional expression of a mouse inward rectifier potassium channel. Nature. 1993; 362(6416):127-33. [PubMed: 7680768]

Lawton DM, Furness DN, Lindemann B, Hackney CM. Localization of the glutamate-aspartate transporter, GLAST, in rat taste buds. Eur J Neurosci. 2000; 12(9):3163-71. [PubMed: 10998100]

Lee WS, Hebert SC. ROMK inwardly rectifying ATP-sensitive K+ channel. I. Expression in rat distal nephron segments. Am J Physiol. 1995; 268(6 Pt 2):F1124-F1131. [PubMed: 7611453]

Lin DH, Sterling H, Yang B, Hebert SC, Giebisch G, Wang WH. Protein tyrosine kinase is expressed and regulates ROMK1 location in the cortical collecting duct. Am J Physiol Renal Physiol. 2004a; 286(5):F881-F892. [PubMed: 15075184]

Lin W, Burks CA, Hansen DR, Kinnamon SC, Gilbertson TA. Taste receptor cells express pHsensitive leak K+ channels. J Neurophysiol. 2004b; 92(5):2909-19. [PubMed: 15240769]

Liu L, Hansen DR, Kim I, Gilbertson TA. Expression and characterization of delayed rectifying K+ channels in anterior rat taste buds. Am J Physiol Cell Physiol. 2005; 289(4):C868-C880. [PubMed: 15930148]

Liu X, Singh BB, Ambudkar IS. ATP-dependent activation of K(Ca) and ROMK-type K(ATP) channels in human submandibular gland ductal cells. J Biol Chem. 1999; 274(35):25121-9. [PubMed: 10455193]

Lorenz JN, Baird NR, Judd LM, Noonan WT, Andringa A, Doetschman T, Manning PA, Liu LH, Miller ML, Shull GE. Impaired renal $\mathrm{NaCl}$ absorption in mice lacking the ROMK potassium channel, a model for type II Bartter's syndrome. J Biol Chem. 2002; 277(40):37871-80. [PubMed: 12122007]

Lu M, Wang T, Yan Q, Yang X, Dong K, Knepper MA, Wang W, Giebisch G, Shull GE, Hebert SC. Absence of small conductance $\mathrm{K}+$ channel (SK) activity in apical membranes of thick ascending limb and cortical collecting duct in ROMK (Bartter's) knockout mice. J Biol Chem. 2002; 277(40):37881-7. [PubMed: 12130653]

Lyall V, Alam RI, Phan DQ, Ereso GL, Phan TH, Malik SA, Montrose MH, Chu S, Heck GL, Feldman GM, DeSimone JA. Decrease in rat taste receptor cell intracellular $\mathrm{pH}$ is the proximate stimulus in sour taste transduction. Am J Physiol Cell Physiol. 2001; 281(3):C1005-C1013. [PubMed: 11502578]

McNicholas CM, MacGregor GG, Islas LD, Yang Y, Hebert SC, Giebisch G. pH-dependent modulation of the cloned renal K+ channel, ROMK. Am J Physiol Renal Physiol. 1998; 275:F972-F981.

Mennitt PA, Frindt G, Silver RB, Palmer LG. Potassium restriction downregulates ROMK expression in rat kidney. Am J Physiol Renal Physiol. 2000; 278(6):F916-F924. [PubMed: 10836979]

Merigo F, Benati D, Galie M, Crescimanno C, Osculati F, Sbarbati A. Immunohistochemical localization of cystic fibrosis transmembrane regulator and clara cell secretory protein in taste receptor cells of rat circumvallate papillae. Chem Senses. 2008; 33(3):231-41. [PubMed: 18156603]

Michlig S, Damak S, Le CJ. Claudin-based permeability barriers in taste buds. J Comp Neurol. 2007; 502(6):1003-11. [PubMed: 17447253]

Murray RG. Cellular relations in mouse circumvallate taste buds. Microsc Res Tech. 1993; 26(3):20924. [PubMed: 8241560] 
Nicolas MT, Barhanin J, Reyes R, Dememes D. Cellular localization of TWIK-1, a two-pore-domain potassium channel in the rodent inner ear. Hear Res. 2003; 181(1-2):20-6. [PubMed: 12855359]

Ohmoto M, Matsumoto I, Misaka T, Abe K. Taste receptor cells express voltage-dependent potassium channels in a cell age-specific manner. Chem Senses. 2006; 31(8):739-46. [PubMed: 16873422]

Palmer LG. Potassium secretion and the regulation of distal nephron K channels. Am J Physiol. 1999; 277(6 Pt 2):F821-F825. [PubMed: 10600927]

Pereira E, Chaudhari N, Roper SD. Barriers in mouse taste buds: Dye penetration studies. Chem Senses. 2008; 33:S145. Abstract.

Perez CA, Huang L, Rong M, Kozak JA, Preuss AK, Zhang H, Max M, Margolskee RF. A transient receptor potential channel expressed in taste receptor cells. Nat Neurosci. 2002; 5(11):1169-76. [PubMed: 12368808]

Pumplin DW, Yu C, Smith DV. Light and dark cells of rat vallate taste buds are morphologically distinct cell types. J Comp Neurol. 1997; 378(3):389-410. [PubMed: 9034899]

Richter TA, Dvoryanchikov GA, Chaudhari N, Roper SD. Acid-sensitive two-pore domain potassium (K2P) channels in mouse taste buds. J Neurophysiol. 2004; 92(3):1928-36. [PubMed: 15140906]

Roberts CD, Dvoryanchikov G, Roper SD, Chaudhari N. Interaction between the second messengers cAMP and Ca2+ in mouse presynaptic taste cells. J Physiol. 2009; 587(Pt 8):1657-68. [PubMed: 19221121]

Romanov RA, Rogachevskaja OA, Bystrova MF, Jiang P, Margolskee RF, Kolesnikov SS. Afferent neurotransmission mediated by hemichannels in mammalian taste cells. EMBO J. 2007; 26(3): 657-67. [PubMed: 17235286]

Roper SD. Signal transduction and information processing in mammalian taste buds. Pflugers Arch. 2007; 454(5):759-76. [PubMed: 17468883]

Rossler P, Kroner C, Freitag J, Noe J, Breer H. Identification of a phospholipase C beta subtype in rat taste cells. Eur J Cell Biol. 1998; 77(3):253-61. [PubMed: 9860142]

Rozengurt N, Wu SV, Chen MC, Huang C, Sternini C, Rozengurt E. Colocalization of the alphasubunit of gustducin with PYY and GLP-1 in L cells of human colon. Am J Physiol Gastrointest Liver Physiol. 2006; 291(5):G792-G802. [PubMed: 16728727]

Ruknudin A, Schulze DH, Sullivan SK, Lederer WJ, Welling PA. Novel subunit composition of a renal epithelial KATP channel. J Biol Chem. 1998; 273(23):14165-71. [PubMed: 9603917]

Sackin H, Nanazashvili M, Li H, Palmer LG, Walters DE. External K activation of Kir1.1 depends on the $\mathrm{pH}$ gate. Biophys J. 2007; 93(2):L14-L16. [PubMed: 17496015]

Sansom SC, Welling PA. Two channels for one job. Kidney Int. 2007; 72(5):529-30. [PubMed: 17713560]

Schultz JH, Czachurski J, Volk T, Ehmke H, Seller H. Central sympathetic chemosensitivity and Kir1 potassium channels in the cat. Brain Res. 2003; 963(1-2):113-20. [PubMed: 12560116]

Shuck ME, Bock JH, Benjamin CW, Tsai TD, Lee KS, Slightom JL, Bienkowski MJ. Cloning and characterization of multiple forms of the human kidney ROM-K potassium channel. J Biol Chem. 1994; 269(39):24261-70. [PubMed: 7929082]

Simon DB, Karet FE, Rodriguez-Soriano J, Hamdan JH, DiPietro A, Trachtman H, Sanjad SA, Lifton RP. Genetic heterogeneity of Bartter's syndrome revealed by mutations in the $\mathrm{K}+$ channel, ROMK. Nat Genet. 1996; 14(2):152-6. [PubMed: 8841184]

Tizzano M, Dvoryanchikov G, Barrows JK, Kim S, Chaudhari N, Finger TE. Expression of Galpha14 in sweet-transducing taste cells of the posterior tongue. BMC Neurosci. 2008; 9:110. [PubMed: 19014514]

Tomchik SM, Berg S, Kim JW, Chaudhari N, Roper SD. Breadth of tuning and taste coding in mammalian taste buds. J Neurosci. 2007; 27(40):10840-8. [PubMed: 17913917]

Trubey KR, Culpepper S, Maruyama Y, Kinnamon SC, Chaudhari N. Tastants evoke cAMP signal in taste buds that is independent of calcium signaling. Am J Physiol Cell Physiol. 2006; 291(2):C237-C244. [PubMed: 16510847]

Vanoye CG, MacGregor GG, Dong K, Tang L, Buschmann AS, Hall AE, Lu M, Giebisch G, Hebert SC. The carboxyl termini of K(ATP) channels bind nucleotides. J Biol Chem. 2002; 277(26): 23260-70. [PubMed: 11956191] 
Wald H. Regulation of the ROMK potassium channel in the kidney. Exp Nephrol. 1999; 7(3):201-6. [PubMed: 10352359]

Wang H, Iguchi N, Rong Q, Zhou M, Ogunkorode M, Inoue M, Pribitkin EA, Bachmanov AA, Margolskee RF, Pfeifer K, Huang L. Expression of the voltage-gated potassium channel KCNQ1 in mammalian taste bud cells and the effect of its null-mutation on taste preferences. J Comp Neurol. 2009; 512(3):384-98. [PubMed: 19006182]

Wang WH, Giebisch G. Regulation of potassium (K) handling in the renal collecting duct. Pflugers Arch. 2008

Wang Y, Apicella A Jr, Lee SK, Ezcurra M, Slone RD, Goldmit M, Schafer WR, Shaham S, Driscoll M, Bianchi L. A glial DEG/ENaC channel functions with neuronal channel DEG-1 to mediate specific sensory functions in C. elegans. EMBO J. 2008; 27(18):2388-99. [PubMed: 18701922]

Xu JZ, Hall AE, Peterson LN, Bienkowski MJ, Eessalu TE, Hebert SC. Localization of the ROMK protein on apical membranes of rat kidney nephron segments. Am J Physiol. 1997; 273(5 Pt 2):F739-F748. [PubMed: 9374837]

Yamamoto Y, Ishikawa R, Omoe K, Yoshikawa N, Yamaguchi-Yamada M, Taniguchi K. Immunohistochemical distribution of inwardly rectifying $\mathrm{K}+$ channels in the medulla oblongata of the rat. J Vet Med Sci. 2008; 70(3):265-71. [PubMed: 18388426]

Yang J, Jan YN, Jan LY. Determination of the subunit stoichiometry of an inwardly rectifying potassium channel. Neuron. 1995; 15(6):1441-7. [PubMed: 8845166]

Yang R, Crowley HH, Rock ME, Kinnamon JC. Taste cells with synapses in rat circumvallate papillae display SNAP-25- like immunoreactivity. J Comp Neurol. 2000; 424(2):205-15. [PubMed: 10906698]

Yee CL, Yang R, Bottger B, Finger TE, Kinnamon JC. "Type III” cells of rat taste buds: immunohistochemical and ultrastructural studies of neuron-specific enolase, protein gene product 9.5, and serotonin. J Comp Neurol. 2001; 440(1):97-108. [PubMed: 11745610]

Yoshida R, Shigemura N, Sanematsu K, Yasumatsu K, Ishizuka S, Ninomiya Y. Taste responsiveness of fungiform taste cells with action potentials. J Neurophysiol. 2006; 96(6):3088-95. [PubMed: 16971686]

Yu FH, Catterall WA. The VGL-chanome: a protein superfamily specialized for electrical signaling and ionic homeostasis. Sci STKE. 2004; 2004(253):re15. [PubMed: 15467096]

Zhang Y, Hoon MA, Chandrashekar J, Mueller KL, Cook B, Wu D, Zuker CS, Ryba NJ. Coding of sweet, bitter, and umami tastes: different receptor cells sharing similar signaling pathways. Cell. 2003; 112(3):293-301. [PubMed: 12581520]

Zhu G, Liu C, Qu Z, Chanchevalap S, Xu H, Jiang C. CO(2) inhibits specific inward rectifier K(+) channels by decreases in intra- and extracellular pH. J Cell Physiol. 2000; 183(1):53-64.

[PubMed: 10699966] 
A

ROMK1

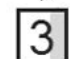

core exon

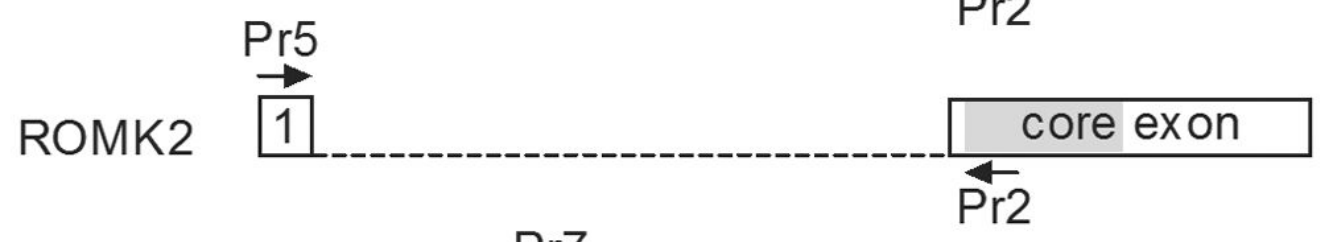

ROMK3

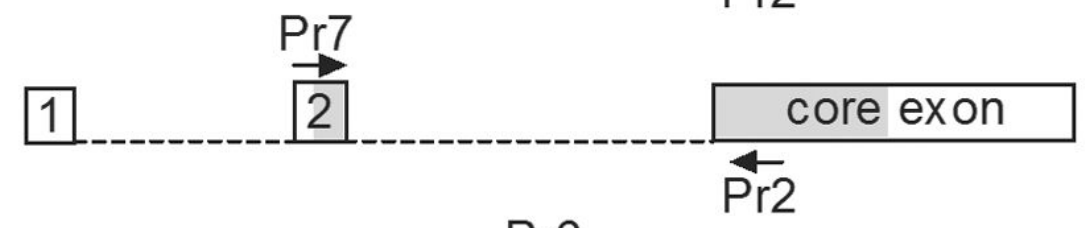

ROMK6

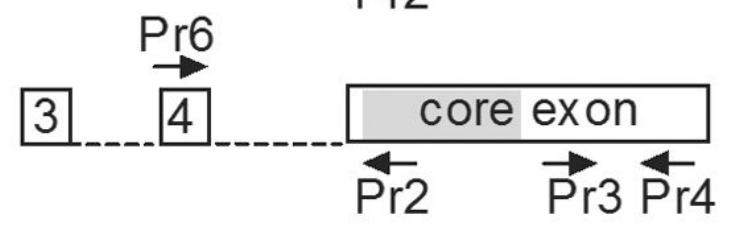

B

kidney
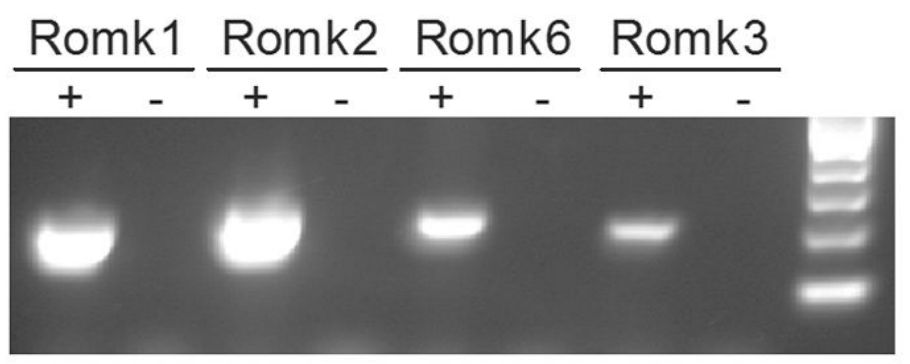

Figure 1. ROMK splice variants in the mouse kidney

A. Schematic diagram of four predicted ROMK splice variants in the mouse, with the position of RT-PCR primers indicated by arrows. Boxes represent exons 1, 2, 3 and 4 and a common core exon included in each of the four alternatively spliced forms. Shaded segments of exons are open reading frames. Dashed lines represent introns that are spliced out. In ROMK6, several in-frame stop codons in exon 4 result in translation from a start codon in the core exon. Thus, the proteins derived from ROMK2 and ROMK6 are identical. B. RT-PCR for ROMK in adult mouse kidney. Individual splice variants were identified through a combination of specific primers and predicted length of product (as shown in A.): Romk1 (primers 1/2; 177bp), Romk2 (primers 5/2; 205bp), Romk3 (primers 7/2; 187bp), Romk6 (primers $6 / 2 ; 202 \mathrm{bp}$ ). Each of these PCR products was sequenced to validate specificity. The negative controls $(-)$ in each case are PCRs lacking cDNA template. 


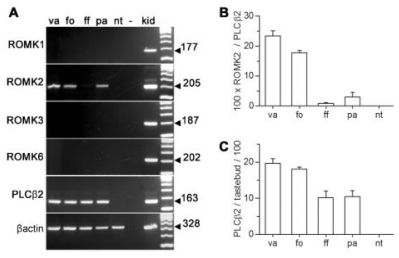

Figure 2. Only the ROMK2 variant is found in taste buds, and at varying concentrations across taste fields

A. RT-PCR for all four ROMK splice variants was carried out on taste buds from four taste fields, vallate (va), foliate (fo), fungiform (ff), and palate (pa) as well as on non-taste epithelium (nt). RT-PCRs on kidney (kid) and water (-) instead of cDNA served as positive and negative controls respectively. The predicted size of the product for each reaction is indicated to the right. Control PCRs for PLC $\beta 2$ (a taste bud-specific protein) and $\beta$-actin (present also in non-taste epithelial cells) were used to validate the quality of each RNA. B. Real-time RT-PCR for ROMK2 in each taste field and in non-taste lingual epithelium.

ROMK2 mRNA copy number for each sample was normalized to PLC $\beta 2$ mRNA copy number. Each plotted value is mean and s.e.m. for three independent taste bud samples, run in parallel and in triplicate. C. Real-time RT-PCR shows that mRNA for PLC $\beta 2$ is at relatively similar copy number in taste buds from the four taste fields (as in B.). The 2-fold lower values for fungiform and palatal taste buds may reflect the somewhat smaller volume of these taste buds and the fewer Type II cells included in them (Boughter Jr et al, 1997). 

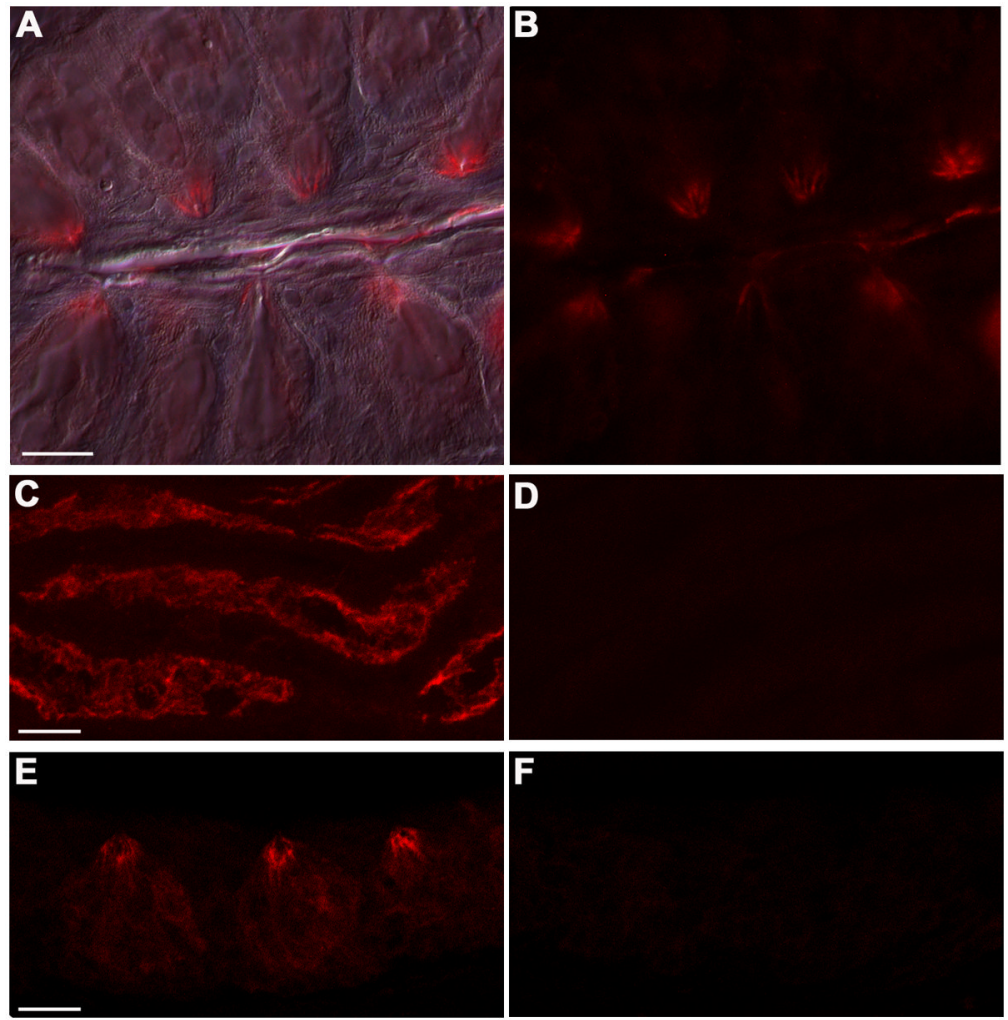

Figure 3. ROMK is located at the apical tips of taste cells

A, B. Sections of vallate papillae were immunostained for ROMK immunofluorescence (red), and merged with a Nomarski DIC image in A. to show the location of taste buds. ROMK immunoreactivity appears concentrated at the apical tips of a few cells in each taste bud. C, D. Validation of the anti-ROMK antibody used throughout this study.

Immunofluorescence in kidney medulla from wild type mice is seen in the apical margin of distal renal tubules as expected (C), while no immunofluorescence signal is detected in the same region of kidney from (D) ROMK knockout mice. E, F. Validation of the ROMK signal seen in taste buds. Immunofluorescence is seen in the apical tips of some taste cells from wild type mice $(\mathbf{E})$ but not in taste buds from $\mathrm{ROMK}^{-1-}$ mice, processed in parallel (F). Scale bars, $20 \mu \mathrm{m}$, apply to left and right pairs of images. Micrographs A, B only are from wide-field microscopy. All other micrographs are confocal. 


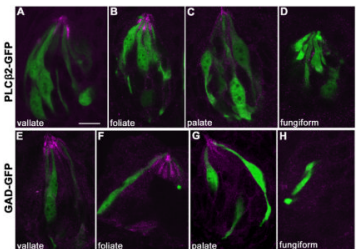

Figure 4. ROMK is not co-expressed in Type II/Receptor cells or Type III/Presynaptic cells A-D. Taste tissue from PLC $\beta 2-G F P$ transgenic mice, was immunostained for ROMK (magenta). In confocal micrographs, immunofluorescence does not overlap with GFPlabeled Type II cells (green) in vallate (A), foliate (B), or palatal (C) taste buds. ROMK is barely detectable in fungiform taste buds (D), consistent with our qRT-PCR data (Figure 2) of minimal mRNA expression in these anterior taste buds. E-H. Taste tissue from GADGFP transgenic mice similarly shows a lack of ROMK immunostaining (magenta) in GFPlabeled Type III taste cells (green) in vallate $(\mathbf{E})$, foliate $(\mathbf{F})$ or palatal $(\mathbf{G})$ taste buds. As above, ROMK was not easily detected in fungiform $(\mathbf{H})$ taste buds. Only the micrograph in A was from a section with tyramide amplification (see Methods). Scale bar, $10 \mu \mathrm{m}$. 


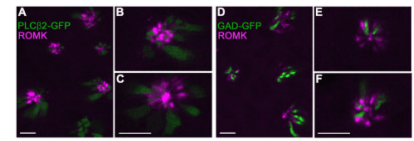

Figure 5. In cross-sections of vallate papillae, ROMK-immunoreactive cells are seen to interdigitate between Type II and Type III cells

Confocal micrographs of cross-sectioned vallate papilla from PLC $\beta 2-G F P$ mice (A-C) or GAD-GFP mice (D-F). ROMK immunoreactivity (magenta) is only near the apical tips of taste buds. At higher magnification $(\mathbf{B}, \mathbf{C}, \mathbf{E}, \mathbf{F})$, in this orientation also, ROMK is seen to be located in cells that are not GFP labeled in each strain (i.e. not Type II or Type III). Instead, ROMK-positive cells are adjacent to GFP-positive cells (green). For all these images, ROMK-immunostaining was visualized by tyramide signal amplification using Alexa 594-conjugated tyramide. Scale bars, $10 \mu \mathrm{m}$. 

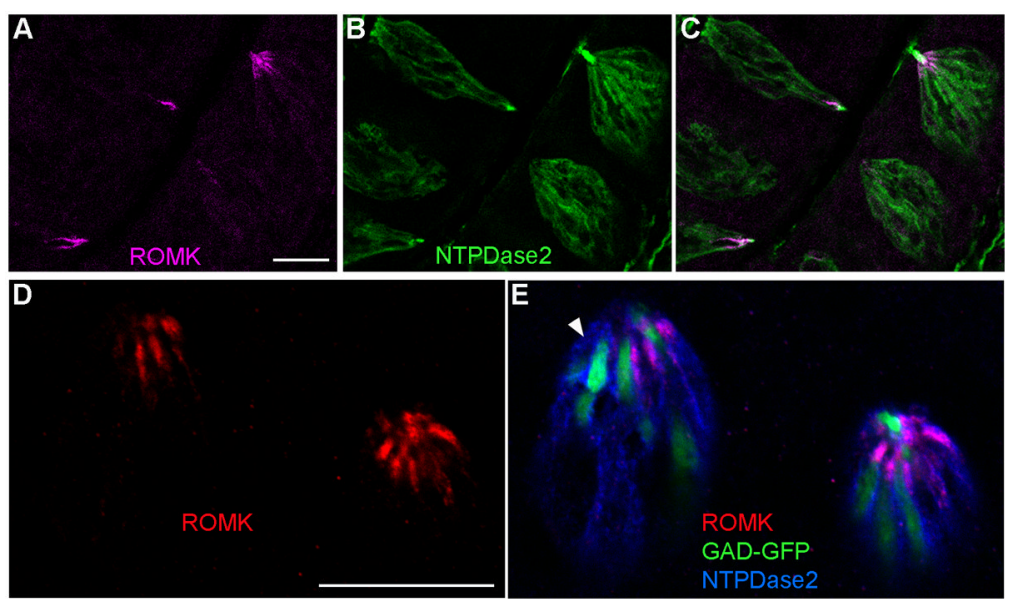

Figure 6. ROMK is expressed in most NTPDase2-positive/glial-like cells

A-C. ROMK immunoreactivity is detected in the same cells that are immunostained for NTPDase2. In these cells from vallate taste buds, ROMK (magenta) is concentrated at the apical tips while NTPDase2 (green) is found throughout the cell membrane. A and $\mathbf{B}$ show each fluorescent signal separately while $\mathbf{C}$ is an overlay of the two. D, $\mathbf{E}$ Three-color visualization with immunoreactivity for ROMK (red) and for NTPDase2 (blue) along with GFP fluorescence (green) which labels Type III/Presynaptic cells in GAD-GFP mice. In the merged image $(\mathbf{E})$, the apical ROMK signal is completely contained within the blue cells and appears magenta. In D, only ROMK immunofluorescence (red) is shown. A few Type I (i.e. NTPDase2-positive) cells do not appear to express ROMK (arrow). Scale bars, $20 \mu \mathrm{m}$. 


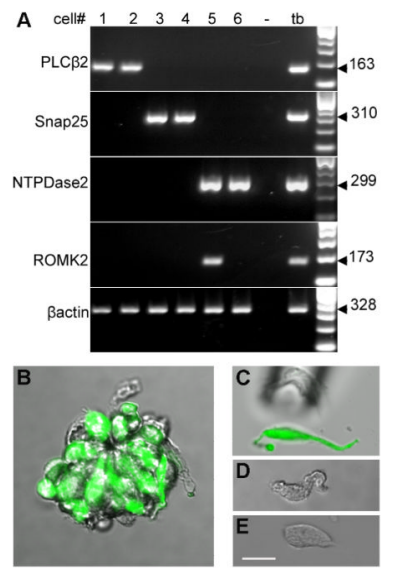

Figure 7. Gene expression profiling of individual taste cells confirms that ROMK is expressed in Type I cells

A. Linear-amplified RNA (aRNA) from individual isolated taste cells was tested by RTPCR for expression of a gene diagnostic for each cell type (top three rows). Two representative cells of each type are shown: \#1, 2 are Type II cells, \#3, 4 are Type III cells while \#5, 6 are Type I cells. ROMK product was detected in one of these two Type I (i.e. NTPDase 2 positive) cells, but in none of the Type II or III cells. The predicted size of the product of each reaction is indicated to the right. The $\beta$-actin RT-PCR validated the quality of each sample. The cDNA from 1 whole taste bud (tb) served as a positive control while a PCR without template (-) is a negative control. B. A substantially improved isolation protocol (see Methods) yields isolated living taste buds that retain their polarized morphology for many tens of minutes. Here, the taste bud was obtained from a (PLC $32+$ GAD)-GFP double transgenic mouse and shows a very large number of GFP labeled cells (all Type II and most Type III). Such taste buds were then triturated very gently to yield well-separated individual cells that can be captured with a fine pipet (as in $\mathbf{C}$ ) after determining if they are GFP-positive (C) or GFP-negative (D, E). As the examples here show, cells retain their polarized morphology even after dissociation from the taste bud. Scale bar, $20 \mu \mathrm{m}$. 


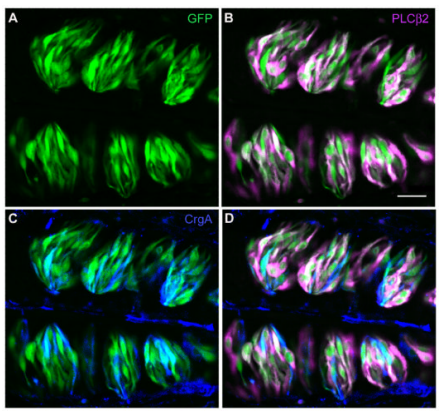

Figure 8. In (PLCß2+GAD)-GFP mice, all Receptor cells and most Presynaptic cells are labeled with GFP

Vallate papilla from a double transgenic mouse was cryosectioned and immunostained for PLC $\beta 2$ and Chromogranin A. A. GFP fluorescence (green) is seen in large numbers of cells in each vallate taste bud. B. Overlay of GFP fluorescence and PLC $\beta 2$ immunofluorescence (magenta). Nearly all PLC $\beta 2$-expressing cells are GFP-positive. C. Overlay of GFP fluorescence (green) and Chromogranin A staining (blue) shows that most, but not all, Chromogranin-expressing taste cells also express GFP. D. Overlay of all three images shows that there are few, if any, GFP-expressing cells that are not labeled with either PLC $\beta 2$ or Chromogranin A. Conversely, the majority of immunostained cells also contain GFP. Occasional cells are seen, stained with chromogranin (blue) only. We recently showed that these form a functionally distinct subset of Presynaptic cells (Roberts et al, 2009). Scale bar, $25 \mu \mathrm{m}$. 

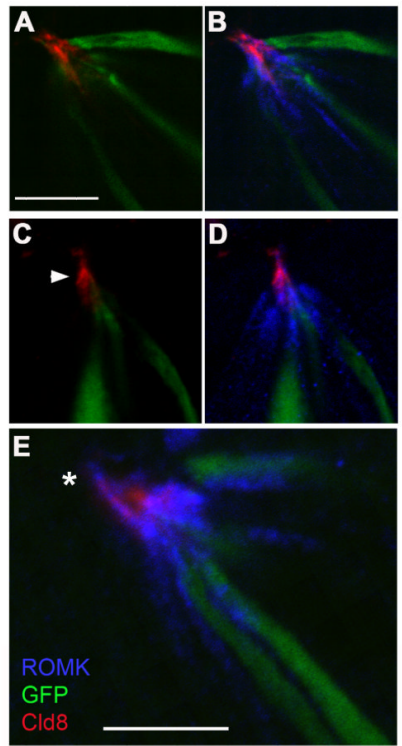

Figure 9. ROMK protein in taste cells extends to the level of apical tight junctions and beyond ROMK was immunodetected using anti-ROMK and Alexa 594-secondary antibody (displayed in blue pseudocolor). The taste buds are from vallate sections from a GAD-GFP mouse; GFP was immunodetected with Alexa 488-conjugated secondary antibody and is displayed green. Tight junctions were visualized using anti-Claudin-8, prelabeled with Alexa 647-Fab fragments, here displayed in red pseudocolor. Three examples of taste buds are shown with Claudin-8 and GFP overlayed $(\mathbf{A}, \mathbf{C})$, or all three antigens overlayed $(\mathbf{B}, \mathbf{D}$, E). Tight junctions (arrowhead) appear to be the apical limit for GFP, a soluble protein in the cytoplasm. In contrast, ROMK is detected in apical processes at the level of tight junctions, and occasionally extending beyond (*in $\mathbf{E})$. All images are single plane $(\approx 1 \mu \mathrm{m}$ depth) confocal micrographs. Scale bar in A applies to panels A-D; all bars, $10 \mu \mathrm{m}$. 


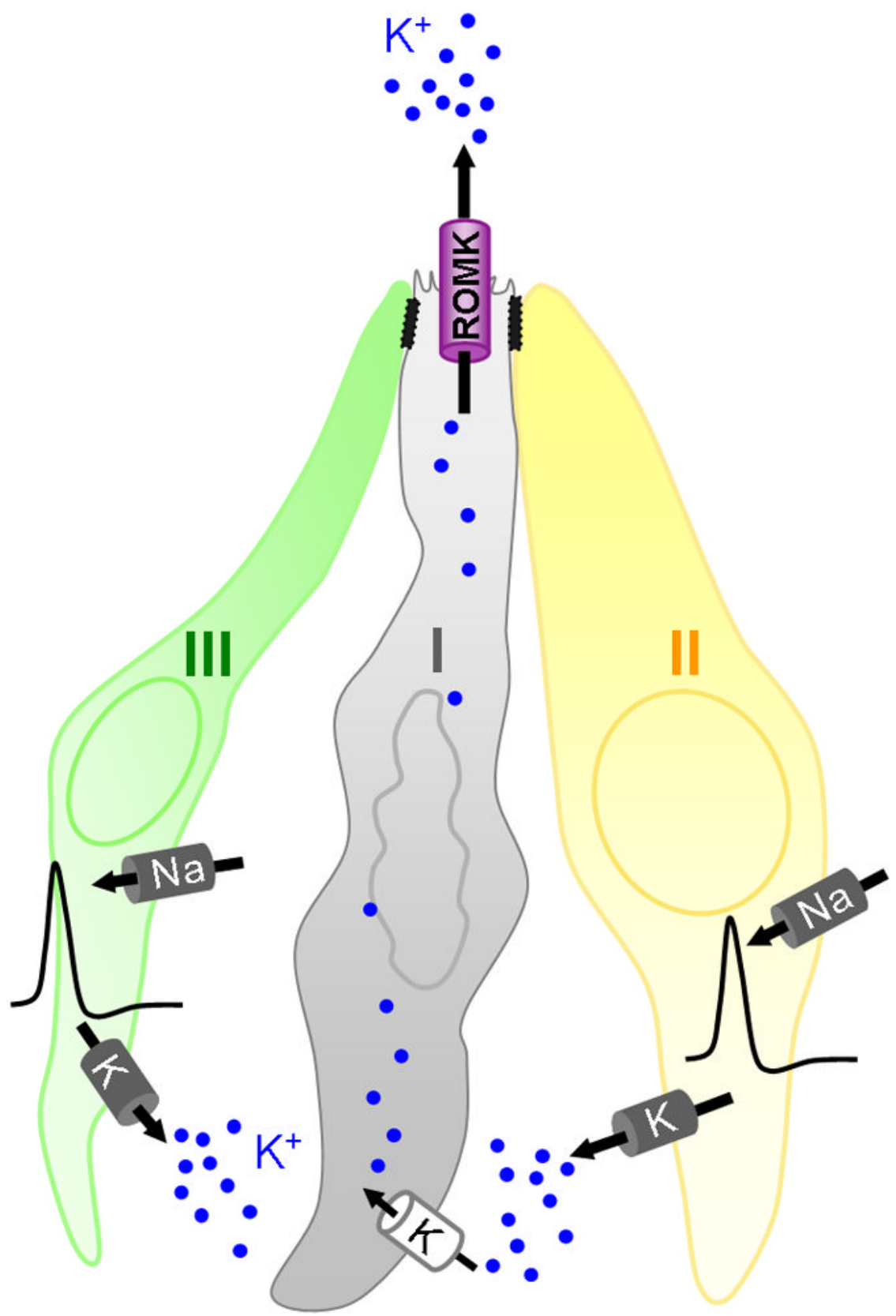

Figure 10. Hypothetical role of ROMK in taste buds

Action potentials in Type II/Receptor and Type III/Presynaptic cells, triggered in response to taste stimulation, are mediated by voltage-gated Na channels such as SCN2A, SCN3A and SCN9A (Gao et al, 2009) and delayed rectifier K (DRK) channels such as KCNA5 (Liu et $a l, 2005)$. Voltage-gated $\mathrm{Na}$ and $\mathrm{K}$ channels are shown as dark cylinders associated with the basolateral membrane of Type II and III cells. Hyperpolarizing DRK currents result in elevation of extracellular $\mathrm{K}^{+}$(black dots), especially following sustained electrical activity. This $\mathrm{K}^{+}$is expected to enter passively (i.e. down its electrochemical gradient) into most cells through "leak" K channels, shown as white cylinders. Type I cells would account for most of the bulk flow of $\mathrm{K}^{+}$out of taste buds because the apical ROMK channel in these cells effectively shunts $\mathrm{K}^{+}$to the external sink, the oral cavity. 


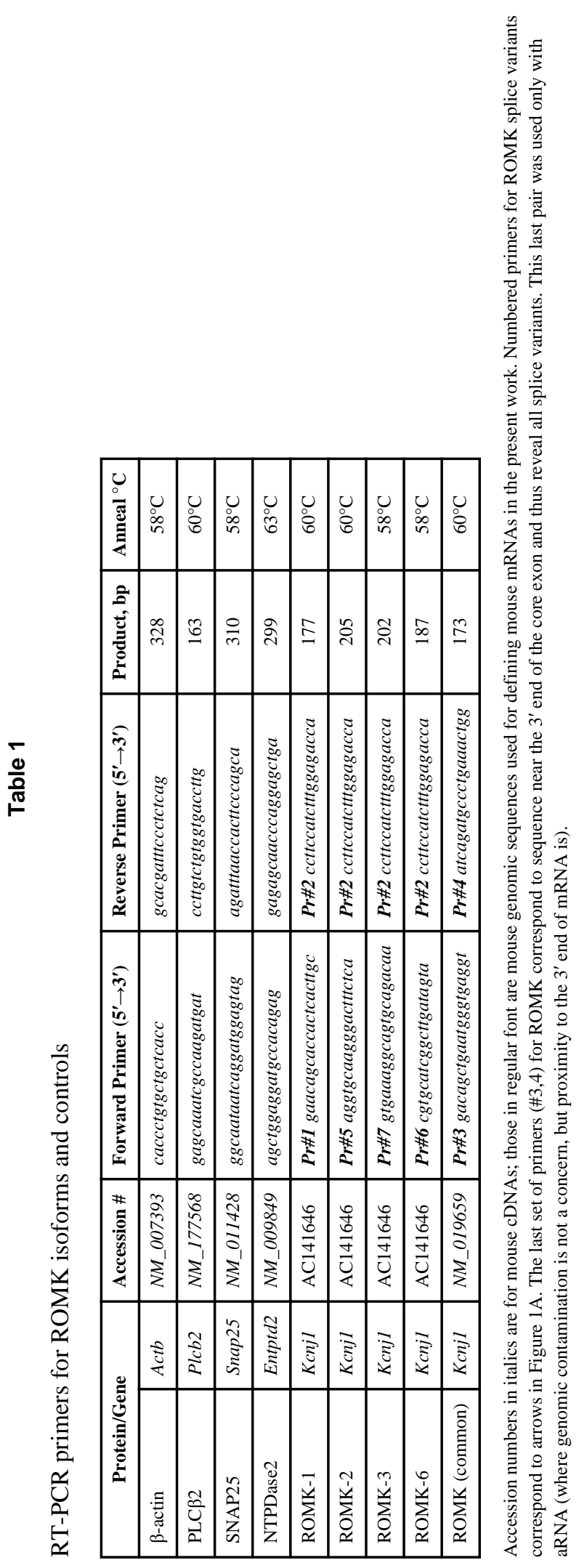

J Comp Neurol. Author manuscript; available in PMC 2011 May 31. 